\title{
Survival Analysis of Chronic Kidney Disease Patients with Hemodialysis in West Java. Indonesia, Year 2007-2018
}

\author{
Afiatin, ${ }^{1}$ Dwi Agustian, ${ }^{2}$ Kurnia Wahyudi, ${ }^{2}$ Pandu Riono, ${ }^{3}$ Rully M. A. Roesli ${ }^{1}$ \\ ${ }^{1}$ Department of Internal Medicine Faculty of Medicine Universitas Padjadjaran/Dr. Hasan Sadikin \\ General Hospital Bandung, Indonesia, ${ }^{2}$ Division of Epidemiology \& Biostatistics Department of Public Health, \\ Faculty of Medicine Universitas Padjadjaran, Bandung, Indonesia, ${ }^{3}$ Department Biostatistics, \\ Faculty of Public Health, Universitas Indonesia, Jakarta, Indonesia
}

\begin{abstract}
The prevalence of chronic kidney disease on dialysis or CKD5D is increasing with a significant impact on disease burden in many countries. Patients are usually listed in the national renal registries, which report demographic data, incidence, prevalence, and outcome. The survival rate is an important outcome measure to characterize the impact of treatment in the CKD5 patient population in the national and international renal registries. Indonesian Society of Nephrology (InaSN) has the Indonesian Renal Registry program to collect data that was endorsed to monitor dialysis treatment quality in Indonesia. IRR releases an annual report, but there is no survival analysis yet. This study aimed to discover the five-year survival rate of CKD5D patients in West Java between 2007-2018 and its factor based on the IRR database. A retrospective cohort study was performed by gaining all patients' data from the IRR database, then data on all of the patients from West Java province who completed a 5-year follow-up on December 31, 2018. Kaplan-Meier analysis and Cox proportional hazard's model were used to analyze the risk factors. There were 3,199 data included in this study. In total, the 1, 2, 3, 4, and 5 year survival rates are 82\%, 70\%, $62 \%, 58 \%$, and $55 \%$, respectively. Patients whose age is above 55 years and with unknown underlying kidney disease have a worse survival rate with a hazard ratio of 1.28 and 1.50, respectively. Further exploration of IRR data will provide better information on dialysis treatment in Indonesia.
\end{abstract}

Key words: Hemodialysis, registry, survival

\section{Ketahanan Hidup Pasien Penyakit Ginjal Kronis dengan Hemodialisis di Jawa Barat Indonesia tahun 2007-2018}

\begin{abstract}
Abstrak
Prevalensi penyakit ginjal kronis pada dialisis atau PGK5D meningkat dan memberi beban penanganan penyakit di banyak negara. Pasien biasanya terdaftar dalam register ginjal nasional yang melaporkan data demografis, insiden, prevalensi dan luaran klisis. Tingkat ketahanan hidup merupakan parameter penting dalam registrasi ginjal untuk menggambarkan kualitas terapi pada populasi pasien PGK stadium 5. Perhimpunan Nefrologi Indonesia (Pernefri) memiliki program Registri Ginjal Indonesia yang disebut Indonesian Renal Registry (IRR) untuk mengumpulkan data pasien PGK5D untuk memantau kualitas pengobatan dialisis di Indonesia. Indonesian Renal Registry merilis laporan tahunan tetapi belum dilengkapi dengan analisis ketahanan hidup. Tujuan penelitian ini adalah mengetahui angka ketahanan hidup lima tahun pasien PGK5D di Jawa Barat antara tahun 2007-2018 dan faktor risikonya berdasarkan basis data dari IRR. Studi kohort retrospektif dengan mengambil semua data pasien dari basis data IRR kemudian ditentukan data pasien Jawa Barat yang lengkap dan di follow up selama 5 tahun pada 31 Desember 2018. Analisis Kaplan-Meier dan model proporsional hazard Cox digunakan untuk menganalisis faktor risiko. Subjek berjumlah 3199 data yang dimasukkan dalam penelitian ini. Kesimpulannya, angka harapan hidup satu, 2, 3, 4, dan 5 tahun berturut-turut adalah 82\%, 70\%, 62\%, 58\%, dan 55\%. Usia lebih dari 55 tahun dan penyakit ginjal yang mendasari memiliki kelangsungan hidup yang lebih buruk dengan hazard ratio 1,28 dan 1,50. Eksplorasi lebih lanjut dari data IRR akan memberikan informasi yang lebih baik tentang perawatan dialisis di Indonesia.
\end{abstract}

Kata kunci: Hemodialisis, ketahanan, registrasi

Corresponding Author: Afiatin, Department of Internal Medicine Faculty of Medicine Universitas Padjadjaran/Dr. Hasan Sadikin General Hospital Bandung, Jalan Pasteur No. 38 Bandung, West Java, Indonesia, Email: afiatin15001@unpad.ac.id 


\section{Introduction}

The prevalence of chronic kidney disease in dialysis or CKD5D patients is increasing with a significant impact of disease burden in many countries (USRDS 2017). ${ }^{1}$ Although various treatment methods have been developed and successfully prolonged patients' lives with endstage kidney disease, the survival rates of CKD5D patients in general remain poor. USRDS reported that the adjusted survival rate for patients on hemodialysis (HD) is $57 \%$ at three years, which is much lower than that of patients on peritoneal dialysis (PD) and patients receiving deceased donor transplantation (58\% and $85 \%$, respectively). ${ }^{1}$

The survival rates of CKD5D patients in different countries vary. For example, people with hemodialysis in Europe have an average of $86.9 \%$ of 1 (one) year survival rate ${ }^{2}$ and the United Kingdom Renal Registry, in particular, has reported a survival rate of $96.6 \%$ in 90 days and $90.4 \%$ in one year. ${ }^{3}$ In contrast with those numbers, in developing countries like Nigeria, the survival rate in 90 days and one year is only $66,8 \%$ and $25 \%$, respectively. ${ }^{4}$

Survival rate is one of the most critical outcome measures and is influenced by individual risk factors, such as the type of underlying kidney disease, age, and comorbidities, as well as the health system factors such as dialysis care facility and financing system. Because the patient survival rate estimation needs valid and reliable data input, since 1977 the International Federation of Renal Registries (IFRR) has endorsed the dialysis registry implementation for every country to monitor dialysis treatment improvement. ${ }^{5}$

The Indonesian Renal Registry (IRR) was established by the Indonesian Society of Nephrology in 2007 and continues to collect patient dialysis data based on voluntary submission from the care units across the country. The participation rate is improving over the years and in 2018 , it $85 \%$ of dialysis units had submitted their data from all areas of Indonesia, with West Java province as the area that contribute most with $95 \%$ of the overall data submitted come from facilities in West Java province area. ${ }^{5}$ Although the IRR annual report has been released since a long time ago, data on survival rate of patient on dialysis was unfortunately reported at that time. The first attempt to estimate the survival rate based on the IRR data was made in 2012 through a collaborative study which resulted in a survival rate of $77.6 \%$ in the first year and $44.3 \%$ in 5 years. Unfortunately, the finding was limited because the IRR data only covered approximately $50 \%$ of all dialysis units in Indonesia at that time.

This study aimed to determine the survival rate and some risk factors of hemodialysis patients in West Java based on the updated Indonesian Renal Registry data. This will potentially provide more reliable information on the survival rate of Indonesian CKD5D patients on dialysis care.

\section{Methods}

This study was a retrospective cohort study that reviewed patients with CKD5 who received maintenance hemodialysis as recorded in the IRR database. The IRR database consists of patient data starting the first dialysis treatment. The patient data include name, gender, date of birth, address, name of the dialysis unit, city, and province of the dialysis unit, date of first dialysis treatment, etiology or underlying kidney disease, comorbid disease, dialysis frequency, date of the last treatment, and cause of finished the treatment. The inclusion criteria were all patients who were registered between January 1, 2007 and December 31, 2018 with complete follow-up information for 5 years at the end of 2018. The IRR admin provided patient data, information regarding date of the first dialysis, age, sex, etiology or underlying kidney disease, and date of the last dialysis as extracted from the database. Patients with incomplete data were excluded from the analysis

The composite endpoint of the analysis was a loss to follow up that means the patient who did not come in 90 consecutive days to the previous dialysis unit or another dialysis unit in Indonesia and cannot be reached by phone or mail and patient who died. We choose 3 kinds of risk factors - gender, age, and etiology of kidney disease category. Patients' follow-ups were censored at the time of death or loss to follow up before the end of 2018. Three variables on survival risk factors comprised sex, age, and etiology of kidney disease were evaluated. Originally the etiology in IRR was classified into ten categories and to reduce the degree of freedom, the classification was simplified into five categories, namely: Primary kidney disease: Primary glomerulopathy and Polycystic kidney disease, Diabetic Kidney Disease, Hypertensive Nephrosclerosis, Other Secondary Kidney Disease: Lupus Nephritis, Pyelonephritis chronic, 


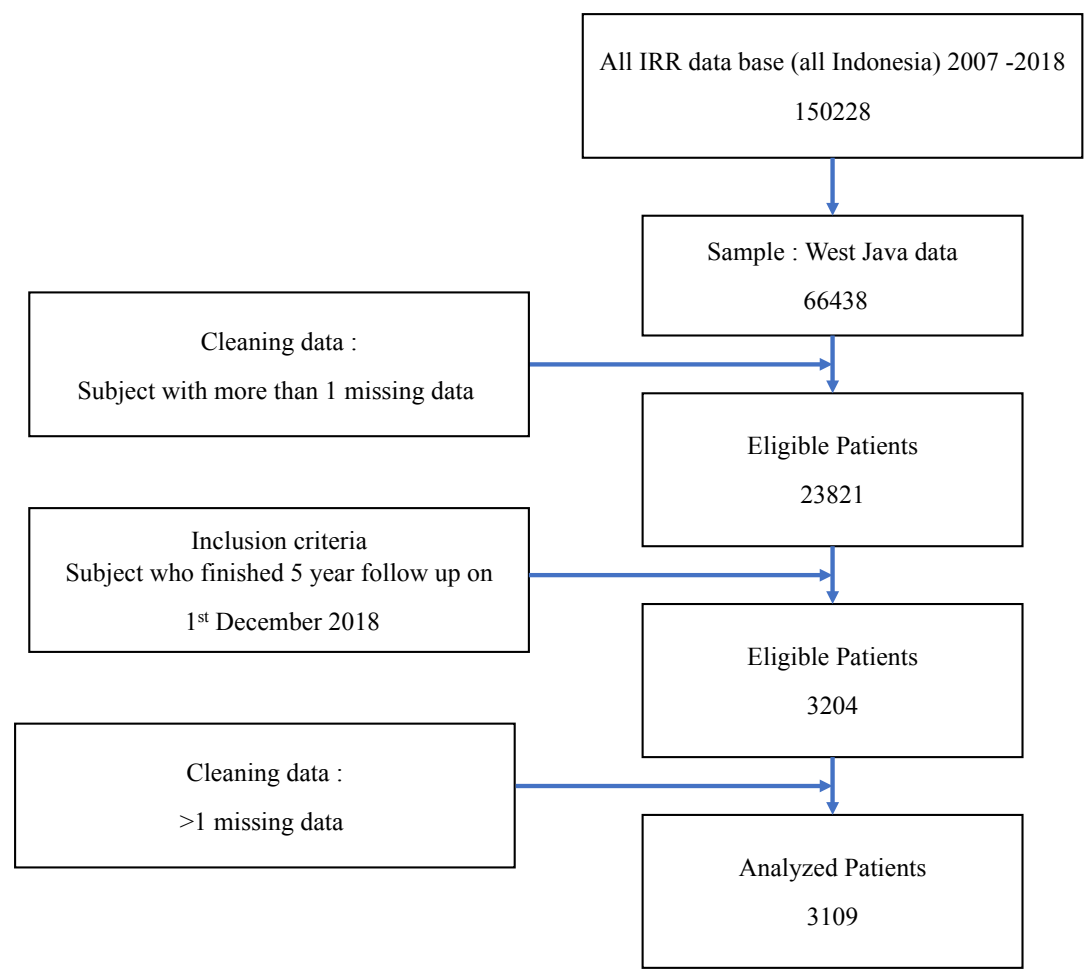

\section{Figure 1 Patient Recruitment Flow Diagram}

Urate Nephropathy, Obstructive Nephropathy, others and Unknown

To maintain the confidentiality of this study, all analyses were using de-identified data. The Ethical Committee Faculty of Medicine University Padjadjaran approved the study protocol (Ethical Clearance Letter No: 33/UN6.KEP/EC/2020).

Descriptive data of subject's characteristics and survival rate were described by medians or means for continuous variables and by number and percentage for categorical variables. KaplanMeier analysis and Cox proportional hazard's model were used to analyze the risk factors. The hazard ratio was calculated for comparison of risk factors by category. The statistical significance was defined at the level of p-values $<0.05$. All statistical calculation was performed by R statistical software version 4.0.2.

\section{Result}

A total of 66,438 patients were in the database of West Java Province. Of these, only 23,821 met the inclusion criteria, and 3,204 patients had complete data for the entire 5 years followup at the end of 2018. There were five patients excluded from the survival analysis due to missing data, resulting in 3,199 patients included in the analysis of survival.

Fifty-six percent of the respondents were male with the median age of 52 years old. Most of the patients (55.1\%) were at the age of 40-59 years. The age groups were further divided into two groups with a cut-off point of 55 years old for risk factor analysis. Twenty-three-point-eight percent of patients had hypertension and 20.5\% of patients had diabetes mellitus as the etiology of chronic kidney disease.

Out of 3,199 patients, 1,431 (47.4\%) finished the treatment as an event. The median length of patients with hemodialysis was 376 days for loss to follow up and 787 days for patients who died.

There was no significant difference in survival when the two genders were compared. There was a significant difference between below and above 55 years old.

A significant difference was seen in terms of patient survival. Patients with hypertensive nephrosclerosis had better survival, followed by patients with diabetic kidney disease, primary kidney disease, other secondary kidney diseases, and unknown 
Table 1 Respondent Characteristics

\begin{tabular}{lc}
\hline \multicolumn{1}{c}{$\begin{array}{c}\text { Characteristics } \\
(\mathbf{n = 3 , 1 9 9 )}\end{array}$} & $\begin{array}{c}\text { Total } \\
\mathbf{( \% )}\end{array}$ \\
\hline Gender, frequency (\%) & $1804(56,3)$ \\
Male & $1395(43,7)$ \\
Female & $52(7,95)$ \\
Age (year), median (min, max) & \\
Group Age, frequency (\%) & $1967(61,5)$ \\
$\quad<55$ year & $1232(38,5)$ \\
$\quad \geq 55$ year & $413(12,9)$ \\
Underlying kidney disease & $656(20,5)$ \\
Primary glomerulopathy & $761(23,8)$ \\
Diabetic kidney disease & $1141(35.6)$ \\
Hypertensive nephrosclerosis & $232(7,2)$ \\
Other secondary kidney diseases & \\
Unknown &
\end{tabular}

\section{Discussion}

In this cohort study, data from the IRR database were used. The dialysis unit has to upload data online of every single patient who undergoes dialysis since their first treatment and should report again when they end the treatment for any reason. The IRR collects some demographic variables, clinical condition variables, dialysis prescription including adequacy assessment, laboratory results, and cause of death. Data were updated every six months and the IRR publishes its report annually in online and print versions. IRR always welcome providing data of
Table 2 Patient Outcome

\begin{tabular}{lc}
\hline $\begin{array}{c}\text { Outcome: } \\
(\mathbf{n = 1 , 4 3 1 )}\end{array}$ & $\begin{array}{c}\text { Median (days) } \\
\text { Minimum-maximum }\end{array}$ \\
\hline Loss to follow up & $376(1-3797)$ \\
Death & $787(1-4811)$ \\
\hline
\end{tabular}

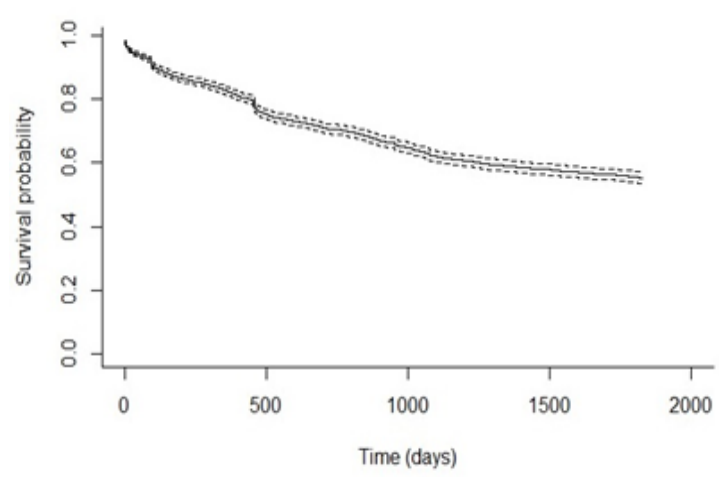

Figure 2 Kaplan Meier- Survival of all patient's

scientific research purpose.

The uptake of data collection was not very good in the beginning, which was 13 years ago, and is getting better recently. InaSN has 12 region coordinators and the IRR admin evaluates the data uptake based on these regions. Every region has a person in charge (PIC) who evaluates the problems of data sending in their regions. West Java province has been succeeded in sending their patient data since the beginning with complete data uptake of always more than $90 \%$ annually. West Java is the province with the biggest population size in the country which is still growing until now. The population of this

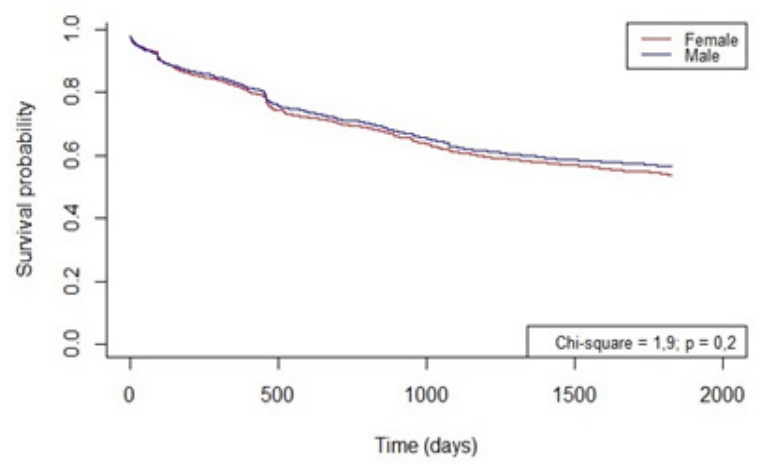

Figure 3 Kaplan-Meier-Patient Survival as Stratified by Gender

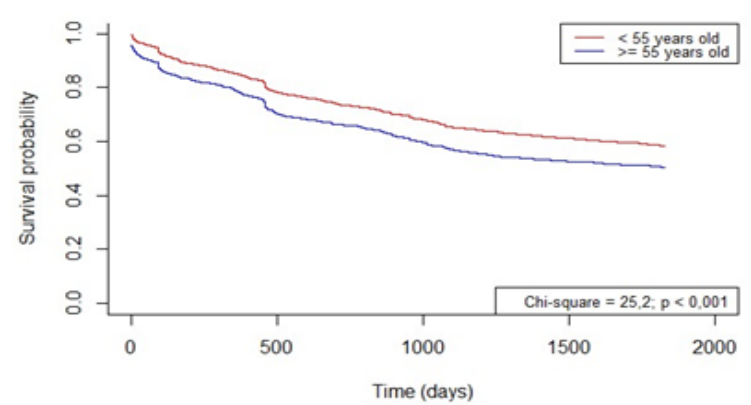

Figure 4 Kaplan-Meier-Patient Survival as Stratified by Age Group 
Table 3 Survival Rate

\begin{tabular}{|c|c|c|c|c|c|}
\hline \multirow[b]{2}{*}{ Year } & \multicolumn{5}{|c|}{$\begin{array}{c}\text { Survival Rate (\%) } \\
95 \% \text { CI }\end{array}$} \\
\hline & 1 & 2 & 3 & 4 & 5 \\
\hline \multicolumn{6}{|l|}{ Covariates } \\
\hline Total & $\begin{array}{c}82.4 \\
(81.1-83.7)\end{array}$ & $\begin{array}{c}70.6 \\
(69-72.2)\end{array}$ & $\begin{array}{c}62.1 \\
(60.4-63.8)\end{array}$ & $\begin{array}{c}58 \\
(56.3-59.8)\end{array}$ & $\begin{array}{c}55.3 \\
(53.6-57.1)\end{array}$ \\
\hline \multicolumn{6}{|l|}{ Gender } \\
\hline Male & $\begin{array}{c}82.7 \\
(81-84.5)\end{array}$ & $\begin{array}{c}71.1 \\
(69.1-73.2)\end{array}$ & $\begin{array}{c}62.7 \\
(60.6-65.0)\end{array}$ & $\begin{array}{c}58.8 \\
(56.5-61.1)\end{array}$ & $\begin{array}{c}56.5 \\
(54.2-58.8)\end{array}$ \\
\hline Female & $\begin{array}{c}81.9 \\
(79.9-84)\end{array}$ & $\begin{array}{c}69.9 \\
(67.6-72.4)\end{array}$ & $\begin{array}{c}61.2 \\
(58.7-63.8)\end{array}$ & $\begin{array}{c}57.1 \\
(54.5-59.7)\end{array}$ & $\begin{array}{c}53.9 \\
(51.3-56.5)\end{array}$ \\
\hline \multicolumn{6}{|l|}{ Age group } \\
\hline$<55$ year & $\begin{array}{c}84.9 \\
(83.3-86.4)\end{array}$ & $\begin{array}{c}73.5 \\
(71.5-75.4)\end{array}$ & $\begin{array}{c}65.3 \\
(63.2-67.4)\end{array}$ & $\begin{array}{c}61.3 \\
(59.2-63.5)\end{array}$ & $\begin{array}{c}58.4 \\
(56.3-60.6)\end{array}$ \\
\hline$\geq 55$ year & $\begin{array}{c}78.3 \\
(76.1-80.7)\end{array}$ & $\begin{array}{c}66 \\
(63.4-68.7)\end{array}$ & $\begin{array}{c}57.1 \\
(54.4-59.9)\end{array}$ & $\begin{array}{c}52.8 \\
(50.1-55.7)\end{array}$ & $\begin{array}{c}50.5 \\
(47.8-53.4)\end{array}$ \\
\hline \multicolumn{6}{|l|}{ Etiology } \\
\hline $\begin{array}{l}\text { Primary kidney } \\
\text { Disease }\end{array}$ & $\begin{array}{c}83.5 \\
(80-87.2)\end{array}$ & $\begin{array}{c}71.2 \\
(66.9-75.7)\end{array}$ & $\begin{array}{c}62.7 \\
(58.2-67.6)\end{array}$ & $\begin{array}{c}58.6 \\
(54-63.5)\end{array}$ & $\begin{array}{c}54.7 \\
(50.1-59.7)\end{array}$ \\
\hline $\begin{array}{l}\text { Diabetic kidney } \\
\text { Disease }\end{array}$ & $\begin{array}{c}87.8 \\
(85.3-90.3)\end{array}$ & $\begin{array}{c}76.1 \\
(72.9-79.4)\end{array}$ & $\begin{array}{c}66.9 \\
(63.4-70.6)\end{array}$ & $\begin{array}{c}63.3 \\
(59.7-67.1)\end{array}$ & $\begin{array}{c}60.1 \\
(56.4-63.9)\end{array}$ \\
\hline $\begin{array}{l}\text { Hypertensive } \\
\text { Nephrosclerosis }\end{array}$ & $\begin{array}{c}90.8 \\
(88.8-92.9)\end{array}$ & $\begin{array}{c}84.4 \\
(81.8-87)\end{array}$ & $\begin{array}{c}77.1 \\
(74.2-80.2)\end{array}$ & $\begin{array}{c}75 \\
(72-78.2)\end{array}$ & $\begin{array}{c}73.7 \\
(70.7-76.9)\end{array}$ \\
\hline $\begin{array}{l}\text { Secondary kidney } \\
\text { Disease }\end{array}$ & $\begin{array}{c}75 \\
(72.5-77.5)\end{array}$ & $\begin{array}{c}61 \\
(58.3-63.9)\end{array}$ & $\begin{array}{c}52.4 \\
(49.5-55.3)\end{array}$ & $\begin{array}{c}47.9 \\
(45.1-50.9)\end{array}$ & $\begin{array}{c}45.1 \\
(42.3-48.1)\end{array}$ \\
\hline Unknown & $\begin{array}{c}73.7 \\
(68.3-79.6)\end{array}$ & $\begin{array}{c}56 \\
(50-62.8)\end{array}$ & $\begin{array}{c}45.7 \\
(39.7-52.6)\end{array}$ & $\begin{array}{c}36.2 \\
(30.5-43)\end{array}$ & $\begin{array}{c}33.2 \\
(27.7-39.8)\end{array}$ \\
\hline
\end{tabular}

Table 4 Cox Proportional Hazard Model

\begin{tabular}{|c|c|c|c|}
\hline & Hazard Ratio & $\begin{array}{c}95 \% \text { Confidence } \\
\text { Interval }\end{array}$ & p-value \\
\hline \multicolumn{4}{|l|}{ Gender } \\
\hline Female & Reference & - & - \\
\hline Male & 0.89 & $0,798-0.989$ & 0.2 \\
\hline \multicolumn{4}{|l|}{ Age } \\
\hline$<55$ years & Reference & - & - \\
\hline$>55$ years & 1.28 & $0.780-1.148$ & 0.001 \\
\hline \multicolumn{4}{|l|}{ Underlying kidney disease } \\
\hline Primary kidney disease & reference & - & - \\
\hline Diabetic kidney disease & 0.75 & $0.619-0.913$ & 0.01 \\
\hline Hypertensive nephrosclerosis & 0.46 & $0.375-0.566$ & 0.001 \\
\hline Other secondary kidney disease & 1.24 & $1.048-1.469$ & 0.05 \\
\hline Unknown & 1.50 & $1.203-1.888$ & 0.001 \\
\hline
\end{tabular}




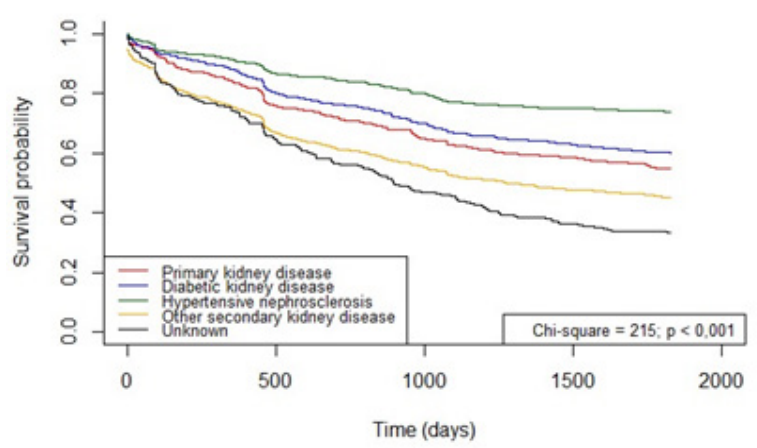

Figure 5 Kaplan-Meier of Patients Stratified by Underlying Kidney Disease

province was 42 million in 2009 and increases to 49.02 million in 2019 , comprising of 18.9 $\%$ of the total population of Indonesia (269.6 million). ${ }^{5}$ The IRR has launched many programs to increase data uptake from other regions. Fortunately, in the last 3 years, the national data uptake has achieved more than $80 \%$. There are about 200,000 hemodialysis patients recorded in the IRR database at the end of 2018. ${ }^{5}$

Not many countries in the world perform survival analysis based on a national renal registry report. Some countries have a perfect registry, such as the United Kingdom Renal Registry, Australia and New Zealand Data, Malaysian Renal Registry, and ERA EDTA Renal Registry. These registries have established excellent quality in data analysis and reporting. The IRR follows their paths to improve the registry. The quality of the database in the registry should be maintained to give a perfect result. The survival rate should be included in the registry report to give a complete description of dialysis treatment in Indonesia.

In this cohort study, data were obtained very easily. The IRR provided the data set that was already cleaned in the excel format. A final check was performed and only five records have five missing data out of 3,204 patients. The number of subjects was significant enough when compared to other five-year survival analysis studies based on the registry. ${ }^{6-11}$ This study analyzed the survival as stratified by age, gender, and underlying kidney disease, which is similar to others.$^{6-17}$.

One year survival rate was $82.4 \%$, similar with the rate in Taiwan in $2009(81.1)^{8}$, Kelantan Malaysia $2018(89.5)^{14}$ and Iran $2010(89.2)^{15,}$ but lower than the Singapore Renal Registry $2017(90.5)^{6}$, Malaysian Renal Registry 2016 $(94)^{7}$, South African Registry 2018 (90.1) , Finnish Registry $2012(89.9)^{10}$, and ANZ Data $2016(94)^{11}$. The survival in this study is better than the USRDS 2018 78.3 ${ }^{1}$, Iran $2018(65)^{16}$, and Nigeria $2019(24.8 \%)^{18}$. Interestingly, the present study showed a 5-year survival rate of $55.3 \%$, which is better than Taiwan $(44.2)^{8}$ and USRDS (42.07) ${ }^{1}$, but similar to Malaysian Renal Registry (53) ${ }^{7}$ and lower than Singapore Renal Registry (61.1) ${ }^{8}$ and Australia and New Zealand Data $(69 \%)^{11}$.

In this registry-based study, gender does not relate to survival and it is similar to SRR and MRR. ${ }^{6.7}$ Age is established as a risk factor for survival, and this study chose 55 years old as cutoff based on the age of retirement in Indonesia. Age more than 55 years old shows significantly worse survival with Hazard Ratio (HR) 1.28. Other studies also show a similar result that older patient has worse survival as in USRDS, SRR, MRR, UKRR, ERA EDTARegistry, Japan Registry, and ANZData. However, those studies use different age grouping and HR increased as the age grouping older. ${ }^{1.2,4,6,7,11}$

As age, underlying kidney disease was known as a risk factor for survival. Diabetic Kidney Disease was known as a leading cause of CKD in many countries. ${ }^{1,2,7}$ Most survival analyses compare diabetic and non-diabetic as underlying kidney disease and exhibit diabetic patients to have worse survival than non-diabetic patients. ${ }^{6.10,17,18}$ Report of IRR shows that diabetes is not the leading cause but hypertension is. ${ }^{6}$ Some registries or countries also report that diabetes is not the leading cause of CKD. ${ }^{12,18}$ The incidence of hypertensive kidney disease varies around the world. For instance, it accounts for as many as $25 \%$ and $17 \%$ of patients starting dialysis for end-stage kidney disease in Italy and France, respectively. Japan and China have lower numbers. Hypertensive kidney disease increases globally since the year of 2000 by 8.7 $\%$. Hypertension is not always reported as the specific cause of kidney disease, therefore, the number may be underestimated. ${ }^{20}$ According to IRR data, the underlying kidney disease groups were categorized into 5 categories in this study, i.e. Primary Kidney Disease (or Primary glomerulopathy), Diabetic Kidney Disease, Hypertensive Nephrosclerosis/ Hypertensive Kidney Disease, Other Secondary Kidney Disease (Lupus Nephritis, Urate Nephropathy, Chronic Pyelonephritis, obstructive nephropathy, and others ) and Unknown. In this Cohort study, 
primary kidney disease is a reference for Cox proportional analysis. Patients in the unknown group have a significantly worse outcome with an HR of 1.5, followed by other secondary kidney diseases with an HR of 1.24, Diabetic kidney disease patients have an HR of 0.75 while patients with hypertensive kidney disease have an HR of 0.46 . This finding was in contrast with our expectation since it was presumed that diabetic kidney disease patients have a worse prognosis than other diseases. This result needs to be validated following the wide range of diseases in other secondary kidney diseases or other categories. A possible explanation for this result is that the IRR has no information about the severity of each disease and the comorbid conditions was not included as a risk category in the analysis in this study. A previous study based on the IRR data showed that patients with hypertension as a comorbid have similar survival probability with those who have no hypertension. MRR presented the same result, stating that patients with unknown underlying kidney disease has worse survival than others with an HR of 1.39 . $^{7}$

The present study has several significant limitations, including no multivariate analysis of risk factors for survival such as comorbid condition, dialysis adequacy, nutritional status, and health facility factors. Indonesia, as a big developing country, had no national health insurance system during the period recorded in the IRR. Most patients paid their dialysis treatment out of their pocket. The financing system might influence the survival as well as dialysis unit shortage

Despite these limitations, the present study provided some useful information. The survival rate in Indonesia as a developing country is not worse than in some developed countries. This result gives valuable information to all stakeholders in making better policies for delivering dialysis service in Indonesia.

In conclusion, 1-,2-,3-,4-, and 5-year survival rates are $82,70,62,58$, and 55\% respectively. Age and underlying kidney disease become the risk factors. Further exploration of IRR data will give better information about dialysis treatment in Indonesia.

\section{References}

1. Saran R, Robinson B, Abbott KC, Agodoa LYC, Gresham JB, Balkrishnan R. et al. US Renal Data System 2018 Annual Data Report: epidemiology of kidney disease in the United States. Am J Kidney Dis. 2019;73(3)(suppl 1):S1-772.

2. Pippias M, Stel VS, Diez JMA, Afentakis N, Herrero CJA, Arias M, et al. Renal replacement therapy in Europe: A summary of the 2012 ERA-EDTA Registry Annual Report. Clin Kidney J. 2015;8(3):248-61.

3. Dada SA, Inubile AJ, Thomas AA, Dada OE, Akinyemi RO. Survival Pattern of Patients on Maintenance Haemodialysis for End-Stage Renal Disease in a Nigerian Dialysis Centre. Arch Nephrol Urol. 2019;2(1):001-12.

4. UK Renal Registry (2019) UK Renal Registry 21st Annual Report - data to 31/12/2017, Bristol, UK. [cited 2020 Januari 12]. Available from: https://www.renalreg.org/ publications-reports/.

5. 11th Indonesian Renal Registry Report 2018. [cited 2019 November 23]. Available from: http.// www.indonesianrenalregistry.org.id

6. Singapore Renal Registry Annual Report 2017. National Registry of Diseases Office 2019. [cited 2020 January 12]. Available from: https://www.nrdo.gov.sg/docs/ librariesprovider3/default-documentlibrary/singapore-renal-registry-annualreport-2016_1999-till-2016_v5_online_final. pdf?sfvrsn $=0$

7. Goh BL, Wong H-S, Ahmad G. 24th Report of The Malaysian Dialysis \& Transplant Registry 2019. [cited 2020 Januari 12]. Available from: https://www.msn.org.my/msn/Doc/ PublicDoc_PB/Publication/mdtr2016/ All\%20Chapters.pdf

8. Wu MS, Wu IW, Hsu KH. Survival Analysis of Taiwan Renal Registry Data System (TWRDS) 2000-2009. Acta Nephrol. 2012;26(2):1048.

9. Jardine T, Wong E, Steenkamp R, Caskey FJ, Davids MR. Survival of South African patients on renal replacement therapy. Clin Kidney J. 2020;13(5):782-90.

10. Haapio M, Helve J, Grönhagen-Riska C, Finne P. One- and 2-Year Mortality Prediction for Patients Starting Chronic Dialysis. Kidney Int Reports. 2017;2(6):1176-85.

11. ANZDATA Registry. 42nd Report, Chapter 3: Mortality in End Stage Kidney Disease. Australia and New Zealand Dialysis and Transplant Registry, Adelaide, Australia. 2019. [cited 2020 Januari 12]. Available from: http://www.anzdata.org.au

12. Neovius M, Jacobson SH, Eriksson JK, Elinder CG, Hylander B. Mortality in chronic kidney disease and renal replacement therapy: A 
population-based cohort study. BMJ Open. 2014;4(2):e004251.

13. Zou Y, Hong D, He Q, Wen Y, Li G. Epidemiology investigation and analysis of patients with haemodialysis in Sichuan province of China. Ren Fail. 2019;41(1):644-9.

14. Ingrid $P$, Adnan $A$, Imran $K$, Fatah AAW. Predictive factors of first-year mortality in newly diagnosed end-stage renal disease patients commencing on haemodialysis in Kelantan, Malaysia. Science Forecast Publications LLC. 2018;1(1):1004.

15. Beladi Mousavi SS, Hayati F, Alemzadeh Ansari MJ, Valavi E, Cheraghian B, Shahbazian $\mathrm{H}$, et al. Survival at 1,3 , and 5 years in diabetic and non-diabetic patients on haemodialysis. Iran J Kidney Dis. 2010;4:74-7.

16. Khazaei S, Yaseri M, Nematollahi S, Zobdeh Z, Sheikh, Mansournia M. Survival Rate and Predictors of Mortality among Haemodialysis Patients in West of Iran, 1996-2015. Int J
Prev Med. 2018;9:113.

17. Belino C, Coelho A, Pereira S, Lopes D, Gomes AM, Ventura A. Survival of haemodialysis patients: A new reality?. Port J Nephrol Hypert. 2017;31(1):37-41.

18. Purnama D, Riono P, Farid MN, Afiatin. The impact of diabetes mellitus and hypertension as comorbid on survival rate chronic kidney disease on chronic haemodialysis patients (indonesian renal registry report analysis 2007-2012). J Hypertens Suppl. 2015;33:e13-e14.

19. Yu SB, Yuan H, Salerno S, Gou SJ, Chen WW, Yang HL, et al. Risk factors for mortality at beginning of maintenance haemodialysis. Chin Med J. 2020;133(7):868-70.

20. Tsur N, Menashe I, Haviv YS. Risk factors before dialysis predominate as mortality predictors in diabetic maintenance dialysis patients. Sci Rep. 2019;9(1):10633. 